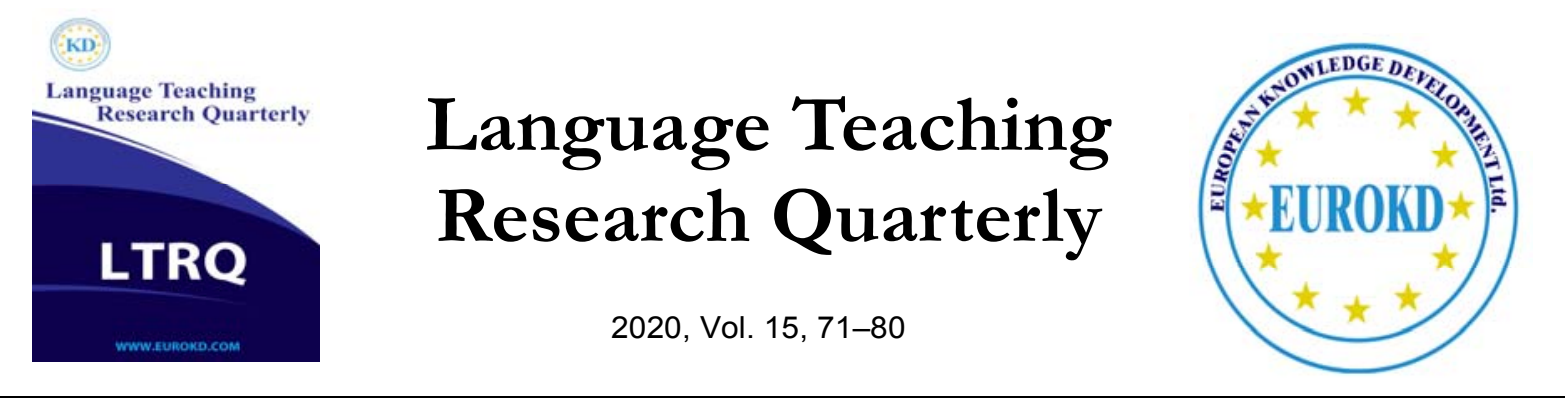

\title{
A Career Impacted
}

Phil Quirke

Education Faculty, Higher Colleges of Technology, UAE

\author{
Future Perspectives and Challenges of Materials Development \\ In Honor of Brian Tomlinson's Contribution to Materials Development Research
}

Received 12 September 2019

Accepted 25 December 2019

\section{Introduction}

When I was first contacted to contribute to this book, my first reaction was one of honour that the editors had thought of asking me to recognise the work of one of the most influential professionals in our English Language Teaching profession, as well as a feeling of excitement that I could pay tribute to a man who has deeply impacted my career although I have seldom managed to acknowledge that influence directly.

We all know the facts behind Dr. Brian Tomlinson's distinguished career and his standing as one of the world's leading experts on materials development in English language teaching and learning. However, it has been his ability to touch the professional lives of so many of us which is truly impressive, and I hope that this journey through my career and how it has been impacted by his work will not only resonate with you as readers but also introduce you to some of his work that you may not have been familiar with.

\section{The Early Years}

My first introduction to the work of Tomlinson came during my first uncertain steps into the world of English language teaching when I took the Certificate in English Language Teaching to Adults (CELTA) course at International House in London in May 1986. A couple of close 
friends had both taken the course and told me that I would find my calling, and they were totally correct. The course gave me the passion for language, learning and teaching that still beats inside me to this day.

There were three works by Brian Tomlinson that I still remember from that course. The first was Discover English (Bolitho \& Tomlinson, 1980), which was required reading and support as part of the language discovery exercises that had to be completed and submitted before the course began. Having never done any formal grammar study before this, I found the exercises daunting to say the least, but to this day I still remember how the book helped me with its clarity and simplicity leaving me with the motivation to learn how I could break down the language from real use to a usage form I could present confidently to my future learners.

The other two works that I was introduced to during the CELTA course were in the sessions on coursebooks and their evaluation. The key text for these lessons was Cunningsworth's Evaluating and Selecting EFL Teaching Material (1984), which was used to evaluate a selection of coursebooks including English through Situations (Ellis \& Tomlinson, 1973-1974). Whilst I have little memory of the key text and the coursebook, I clearly remember the influence that Tomlinson's Glossary of ELT Terms (Cunningsworth, 1984: 80-102) had on my own terminology dictionary that I was compiling as part of the course. The learning impact this terminology dictionary had on my studies resulted in me still using terminology dictionaries in all my teacher training courses to date.

On completion of the CELTA, I was able to take on my first English language teaching jobs in a couple of small language schools in Cologne, Germany, before landing a steady contract with Linguarama, who specialised in Business English courses for many of the leading companies in the region. Linguarama followed a skills-based programme around business situations and themes using in-house developed coursebooks. Whilst following these closely and finding them extremely useful as a novice teacher, I was also able to draw upon a number of new textbooks to support the student learning supplied by the institution in their resource room. Two of those I drew extensively from were Reading Upper Intermediate (Tomlinson \& Ellis, 1987) and Speaking Intermediate(Ellis \& Tomlinson, 1987). The way in which each unit was divided into tasks based on a text and advice on specific language sub-skills acted as a perfect supplement to the Linguarama coursebook units, and again my teaching developed and matured thanks to Tomlinson's materials and approach to language teaching.

Based on the two years' experience in English for Specific Purposes teaching with Linguarama, I was able to get a job with the British Council in Caracas, Venezuela to focus on their Business English and company specific courses. I continued to use the Oxford Supplementary Series in my teaching not least because students found its fluency-focused, taskbased, problem-solving approach motivating and I found that I could relate the unit texts to student experiences easily. I drew heavily on the Reading Advanced book (Tomlinson \& Ellis, 1988) as at that time it was difficult to find effective materials for the higher levels and I had a couple of advanced classes who needed challenging. It is one of the dog-eared tomes still on my bookshelves at home. 
My confidence in my ability to deliver innovative classroom learning opportunities was growing and when the British Council echoed this belief in my ability with an offer to take the Diploma in English Language Teaching for Adults (DELTA) in return for a further two-year contract, I began to seriously consider the fact that this could be my lifetime career.

\section{A Career Born}

It was the DELTA which confirmed to me that I had found my chosen career and that I would remain in English Language Teaching and Education for the rest of my career. It was the course that gave me the opportunity to present to other teachers for the first time in 1990 at the International House Business School in London on Forming a Company: Simulation as a Syllabus, which was based on courses I had run for business students of mixed ability in Caracas. On my return to Venezuela I presented my simulations approach at VENTESOL and felt that I had joined the TESOL professional community for the first time.

In 1992, we moved from Venezuela, and I took a job in the UAE working on a Foundations language programme for military cadets. The position involved me authoring a series of pronunciation books and tutoring on the Trinity Licentiate Diploma for English Language Teaching, and it also made me realise I needed to pursue my graduate studies and obtain my Masters. Although I settled on the M.Sc. in Teaching English for Specific Purposes at Aston University, I also considered the MA on Materials Development in Language Learning that Tomlinson had launched at the University of Luton.

One of the sessions I developed for the Licentiate Diploma was called Are you a slave to the coursebook? and its content was clearly influenced by Tomlinson, who captured my message of providing learners with material that supplements and extends the coursebook content when he later stated: "In my view, in order to facilitate the gradual process of acquisition, it

is important for materials to recycle instruction and to provide frequent and ample exposure to the instructed language features in communicative use" (Tomlinson, 1998:17).

In 1993, Brian Tomlinson founded the international materials development association MATSDA and launched the journal Folio, which I had access to during my M.Sc. studies. There were two articles I particularly remember on TPR (Tomlinson, 1994) and dialoguing (Tomlinson, 1995) as both of these influenced my teaching practice and how I was using TPR and dialogues in my classrooms at the time.

My Masters study not only deepened my linguistic and pedagogical content knowledge, but also confirmed that my eclectic, humanistic approach to language teaching and learning was supported by numerous researchers and experts in our TESOL field. It introduced me to the power of classroom-based action research and how teachers can present their work as a soundly examined approach to student learning. With my new-found confidence and as I began to feel a valid member of the TESOL profession, I presented at TESOLArabia on my work on observations and the concept of face and its importance in the classroom, especially in cultures that have a strong sense of group face and community such as the Middle East. 
After moving to Barcelona, Spain for a year, we returned to the UAE having successfully interviewed for an English teaching job with the Higher Colleges of Technology, and I also continued my teacher training work as a tutor on the DELTA programme. It was another two of Tomlinson's articles in Folio in 1997 which influenced by grammar sessions on the DELTA course and started a long exploration of making grammar fun, relevant and real in my classrooms. I was now actively reflecting on my teaching and teacher training and beginning to write professionally with my first articles published in 1996. In an article for the Reading in a Foreign Language journal, Tomlinson (1998:177) states: "It is argued that what we should be doing instead is to encourage learners to establish experiential reading as their norm and sufficient comprehension as their goal and to help them to achieve a multi-dimensional representation of literature which can facilitiate language acquisition, stimulate a willingness to read and develop the confidence and competence required for successful extensive reading." Whilst Tomlinson is talking specifically about reading literature, his argument is one that pervades my approach to student learning and reflection on my teaching as I aim to make the classroom experience an experiential one that facilitates language acquisition and develops student confidence and competence.

\section{Teacher Leadership}

In 1999 I decided to start my doctorate in Teacher Knowledge Development bringing together literature from teacher education, teacher knowledge and web-based training. Although centred on teacher knowledge development the research required diverse reading from other fields, and this approach of connecting literatures from other areas appears to echo the far more prolific Tomlinson, whose work at the time with its focus on materials development connected "areas of linguistics such as language acquisition, sociolinguistics, psycholinguistics, language analysis, discourse analysis and pragmatics, of developing teacher awareness of methodological options, and of improving the effectiveness of materials" (Tomlinson, 2001:71).

As I developed a new Work Readiness Programme for unemployed nationals that required meeting industry defined job-specific language skills and work competencies, I found myself drawing heavily on Tomlinson's publications in 2000 on cultural awareness and simulations as well as listening to his recommendation that materials should "stop catering predominantly for the 'good language learner' (who is analytic, pays attention to form and makes use of learning strategies in a conscious way) and ... start to cater more for the many learners who are experientially inclined" (Tomlinson, 2001:70).

In 2001, my publications in two TESOL volumes on Journal Writing (Burton \& Carroll) and Action Research (Edge) coincided with my first TESOL Convention presentation. For the first time in my career, I felt I was received by internationally recognised writers and speakers as a peer, and the experience solidified my self-confidence in that I had indeed chosen the correct career and made the correct choice of doctoral study. Two years later, I was invited to be the Editor of the Out of the Box section in the new Essential Teacher, and I still remember the honour and surprise that the publications board at TESOL knew my work, approach and beliefs 
so well that they would offer me this section. My editorial work on the section was definitely influenced by Tomlinson's Developing Materials for Language Teaching (2003) and his publications on Humanising the Coursebook (2003), language awareness in the ELT Journal (2003) and cultural awareness in Modern Language Teacher (2004). Later in his career, he wrote: "My position is that materials should not be random recreations from repertoire norcrafty clones of previously successful materials. Instead they should be coherent andprincipled applications of:

i) theories of language acquisition and development

ii) principles of teaching

iii) our current knowledge of how the target language is actually used

iv) the results of systematic observation and evaluation of materials in use" (Tomlinson, 2010:81). I would like to believe that I edited the articles in Out of the Box from the same perspective whilst focusing on innovation, creativity and uniqueness.

At this time, I was also developing an educational management course for my team of twelve Chairs to unify the principles by which we were leading our general education and English teaching departments at the campus. The outcome was the initial draft of my DREAM management philosophy and approach to educational leadership, and in those early days was definitely influenced by two Tomlinson publications. The first was his chapter in the Handbook of Research in Second Language Teaching and Learning (2005) in which he argued that the methodology must suit the social context, and although he was writing about EFL, his argument resonated powerfully with my work on management training. The second was a quote from his article in the ELT Journal (2005:42) on Testing to Learn: "My argument is that the most effective way to prevent assessment tasks from inhibiting the learning process is to make the promotion of learning their primary purpose". This quote spoke to me so strongly that I developed the unit assessments for the DREAM management course around participant reflections on how they had applied the principles in their job.

In 2005, I had the pleasure and privilege of presenting at the TESOL Convention in San Antonio with Julian Edge on Professional Development Opportunities and with Joy Peyton on Journal Writing. These two, who I had always considered, and still do, giants of our field shared their knowledge openly, mentored me continuously and became true friends as well as professional colleagues. Along with Keith Richards and Jill Burton, they epitomise everything that is best about the TESOL profession and community. They share their work, knowledge and expertise freely and willingly, they care deeply about students, learning, teaching and colleagues no matter how experienced they are and above all they never shy away from saying what needs to be said and done in our classrooms and institutions. Whilst I have never had the same personal connection with Brian Tomlinson, he is another of the giants in our field whose work has always spoken to me in the same way. If I can conclude my career having touched a fraction of those these maestros have impacted, I will retire a very happy TESOLer. 


\section{College Leadership}

The central goal of the DREAM educational management approach is student learning and success, and therefore those closest to students - their teachers, are considered the engine of effective institutional leadership. In 2016 I was appointed the founding director of the Madinat Zayed Higher Colleges of Technology followed by the campus in Ruwais the next year, and I had the opportunity to put the approach into practice at an institutional level. This meant building an environment that engaged students in their learning and allowed teachers to be "the richest resources in any classroom" (Tomlinson, 2016:12).

The library was central to both campuses, classrooms designed like a 'majlis' were available for teachers to book and were used regularly for speaking and reading classes, a course on intercultural communication linked the students with peers in Japan and the U.S., and the community were closely involved in creating student learning opportunities such as the Business Lion Den competition for supporting new SME ideas. Initiatives such as these were all generated by teachers and the goal of management was to support faculty and give them the freedom to develop an infectious excitement of learning throughout the two colleges. These samples are an indication of what is feasible when the focus is on student learning rather than teaching, the coursebook, the syllabus, or a final exam. When student engagement in their learning is the primary focus, other goals will be attained as students become excited about their learning. Whilst the DREAM approach is focused on educational management, the principles echo Tomlinson's beliefs whether he is writing about language acquisition (2007) or teaching materials (2008a). The DREAM principles echo the humanistic principles Tomlinson lists in his article in Humanising Language Teaching (2008b): localization, personalisation, flexibility, multi-dimensional representation, cognitive stimulus and affective engagement, and as he noted in the same article, the positive impact they have on student motivation and achievement has been widely recorded.

"Only by pooling resources will we ever be able to answer some of the questions which we need to ask if we are to really increase the effectiveness of the materials which we produce" (Tomlinson, 2011: 442). I believe this is not only true about second language teaching materials, but also about education, learning, and educational management. My career has always been driven by collaboration and not competition, and my experience has consistently proven that it is teamwork and collective action that has provided the best opportunities for students to attain their learning goals.

Technology and its advancement have opened up global access possibilities for students to access knowledge and support for their learning, and whilst many online learning sites and courses initially regressed to an outdated methodology of delivery, "social networking sites, blogs, virtual worlds, and cell phones have started to be used not only as ways to transmit language learning materials but as means for providing opportunities for communicative interaction" (Tomlinson, 2012: 274). The intercultural communication course example above where students from the Al Gharbia region of the UAE connected to peers in the U.S.A. and Japan is but one exciting early example of how technology can enhance learning opportunities, 
but the possibilities are limitless and the ever-faster development of technology in fields such as neuro-science is providing all educators with the potential to create contextualized, collaborative and cognitively challenging courses, materials and tasks that connect students locally, regionally and internationally as required.

Throughout the seven years as Director of the two campuses in the Western Region I continued to run the DREAM management course with my team, exploring different technological mediums and developing an approach to online instruction that follows an input discussion - situated task - reflection format, which at the input stage draws heavily on Tomlinson's text-driven approach that selects "written and spoken texts with a potential for affective and cognitive engagement", and which develops the situated tasks following Tomlinson's advice to "consult learners, teachers and administrators before, during and after the materials writing process" (2013:3).

\section{The Latter Years}

After returning from the Western Region, I took over the leadership of the Education Faculty and continue my work on educational management and leadership training, reflective writing and online course development. Brian Tomlinson's work continues to influence and inspire. I have drawn on his 'in design', 'as designed', 'in action' and 'in reflection' materials evaluation stages for on-going reviews of my DREAM management and teacher education courses.

"Materials in design are those that are in the process of being developed; materials as designed are those that have been finalized and are in a form ready for use; materials in action are those that are actually in the process of being used, and materials in reflection arethose that are represented when users of the materials recollect their use" (Tomlinson 2017: 2). My own reflection stage as course developer reviewing feedback of participants over all four stages has definitely strengthened the courses I have designed and ensured that they are updated and adapted systematically every time they are delivered. It is a thorough, principled, systematic, evidence-based approach that addresses rapport, impact, course design beliefs and learner motivation in its data collection, and it is an approach I have found especially effective in maintaining learner and participant engagement.

Tomlinson's work (Maley \& Tomlinson, 2017) on different perspectives of authenticity 'text authenticity', 'task authenticity', 'curriculum authenticity', 'learner and teacher authenticity', 'context authenticity', 'theoretical authenticity' - has also impacted my research and teacher education approach over the last few years, providing thought-provoking avenues for developing my courses and my reflective writing work on the theorising of practice and the practicalising of theory.

Most recently, Tomlinson's two articles in The TESOL Encyclopedia of English Language Teaching on Discovery-Based Instruction (2018a) and Blended Learning (2018b) have echoed my own research and understanding of effective learning, teaching, assessment and course design. Discovery-based instruction "is an approach to learning rather than an approach to teaching ... based on the principle that learning is most effective when learners first experience 
something being used", derive intuitions about its use and then investigate it analytically with the teacher helping the learners on this path of knowledge discovery. It is an approach I continually strive to maintain, and it is authors and speakers like Brian Tomlinson who remind me this effort is not a solo enterprise but one that many of us continue to work on.

As "the Internet cannot generate the stimulation, motivation, and supportive feedback that face-to-face contact with teachers and fellow learners can achieve", Tomlinson (2018b) suggests that "the ideal is to combine the best of both worlds by integrating digital and face-to-face learning in an approach which has become known as blended learning (i.e., a principled and coherent combination of two modes of course delivery)." He continues by stating that "designers and deliverers of courses would ideally ensure that nothing is done online that could have been done better face-to-face and vice versa; they have to inform and persuade the students of the benefits of doing a blended learning course; they have to invite and listen to feedback." This again echoes my own experience and whilst I agree with Tomlinson's conclusions and view that blended learning has the potential to be the strongest trend in the future of language learning, my work and research is also pointing to the fact that online technologies now offer us the potential to ensure students can benefit from a fully online learning experience that fulfills all the teacher support and collaborative learner interaction requirements of effective course, text and task design and implementation. Video call and conferencing facilities such as Skype and Zoom, live synchronous classroom forums such as webinars and Collaborate, group chat and messaging services such as WhatsApp and Messenger, and new developments in social media platforms such as Facebook and Twitter, all allow us now to develop courses where students can feel part of a learning group that collaborate and grow together. The future trend I would suggest is towards fully online education and course design as long as the principles that Tomlinson has highlighted throughout his career are adhered to.

\section{Conclusion}

I hope that this trip through my career has resonated with you, the reader, and that I have succeeded in introducing you to some new publications by Brian Tomlinson. I have deliberately ended with his two articles on discovery-based instruction and blended learning as they demonstrate clearly how his work on materials development over the year impacts all our work over numerous fields within TESOL. Thank you, Brian. Your work has continuously informed and inspired us over the last four decades.

\section{REFERENCES}

Bolitho, R \& Tomlinson B. (1980) Discover English. London: George Allen and Unwin.

Bolitho, R., Carter, R., Hughes, R., Ivanic, R., Masuhara, H. and Tomlinson, B. Ten questions about language awareness. (2003) ELT Journal. Vol. 57/2, 251-259.

Burton, J. \& Carroll, M. (Eds) (2001). Journal Writing. Alexandria, VA: TESOL Inc.

Edge, J. (Ed) (2001). Action Research. Alexandria, VA: TESOL Inc. 
Ellis, R \& Tomlinson, B. (1973-74) English Through Situations. Harlow: Longman. Books 1, 2 and 3.

Ellis, R. \& Tomlinson, B. (1987) Speaking Intermediate. Oxford: Oxford University Press.

Maley, A. \& Tomlinson, B. (Eds). (2017) Authenticity in Materials Development for Language Learning. Newcastle: Cambridge Scholars.

Tomlinson, B. \& Ellis, R. (1987) Reading Upper Intermediate. Oxford: Oxford University Press.

Tomlinson, B. \& Ellis, R. (1988) Reading Advanced. Oxford: Oxford University Press.

Tomlinson, B. \& Masuhara, H. (2000) Using simulations on materials development courses. Simulation and Gaming: An Interdisciplinary Journal of Theory, Practice and Research. Vol. 31/2, 152-168.

Tomlinson, B. \& Masuhara, H. (2004) Developing cultural awareness. Modern English Teacher.13/1, 5-11.

Tomlinson, B. \& Masuhara, H. (2017) The Complete Guide to the Theory and Practice of Materials Development for Language Learning. Hoboken, NJ: Wiley.

Tomlinson, B. (1984) Glossary of ELT Terms. In A. Cunningsworth. Evaluating and Selecting EFL Teaching Material. Oxford: Heinemann. 80-102.

Tomlinson, B. (1994) Materials for TPR. FOLIO Vol. 1/2, 8-10.

Tomlinson, B. (1995) Dialogues. What are they for? FOLIO Vol. 2/1, 26-30

Tomlinson, B. (1997) A question of grammar. FOLIO Vol. 3/2, 8-10

Tomlinson, B. (1997) The future perfect. FOLIO Vol. 4/1, 3.

Tomlinson, B. (1998) And now for something not completely different: an approach to language through literature. Reading in a Foreign Language. Vol. 11/2, 177-89.

Tomlinson, B. (2000) Materials for cultural awareness: combining language, literature and culture in the mind. The Language Teacher. Vol. 24/2, 19-21

Tomlinson, B. (2001) Materials development. In R. Carter and D. Nunan (Eds) The Cambridge Guide to Teaching English to Speakers of Other Languages. Cambridge: Cambridge University Press, 66-72.

Tomlinson, B. (2003) Humanising the coursebook. In W. A. Renandya (Ed) Methodology and Materials Design in Language Teaching: Current Perceptions and Practices and their Implications. Singapore: RELC, 12-29.

Tomlinson, B. (2005) Suiting EFL methodologies to social contexts. In E. Hinkel (Ed) Handbook of Research in Second Language Teaching and Learning. Hillsdale, NJ: Lawrence Erlbaum, 137-153.

Tomlinson, B. (2005) Testing to learn. ELT Journal. 59/1, 39-46

Tomlinson, B. (2006) The Resourceful Language Teacher. Alexandria, VA: TESOL Inc.

Tomlinson, B. (2008b) Humanising an EAP coursebook. Humanising Language Teaching. Vol. 10, Issue 2. Retrieved from: http://old.hltmag.co.uk/apr08/sart01.htm

Tomlinson, B. (2010) Principles and procedures of materials development. In N. Harwood (Ed) Materials in ELT: Theory and Practice. Cambridge: Cambridge University Press, 81-108.

Tomlinson, B. (2018a). Discovery-Based Instruction. In J. I. Liontas (Ed) The TESOL Encyclopedia of English Language Teaching. John Wiley \& Sons, Inc. DOI: 10.1002/9781118784235.eelt0057.

Tomlinson, B. (2018b). Discovery-Based Instruction. In J. I. Liontas (Ed) The TESOL Encyclopedia of English Language Teaching. John Wiley \& Sons, Inc. DOI: 10.1002/9781118784235.eelt0941 
Tomlinson, B. (Ed) (1998) Materials Development in Language Teaching. Cambridge: Cambridge University Press. Tomlinson, B. (Ed) (2003) Developing Materials for Language Teaching. London: Continuum.

Tomlinson, B. (Ed) (2007) Language Acquisition and Development: Studies of First and Other Language Learners. London: Continuum.

Tomlinson, B. (Ed) (2008a) English Language Teaching Materials. London: Continuum.

Tomlinson, B. (Ed). (2 ${ }^{\text {nd }}$ Edition, 2013) Developing Materials for Language Teaching. London: Bloomsbury.

Tomlinson, B. (Ed). (2 $2^{\text {nd }}$ Edition, 2011) Materials Development in Language Teaching. Cambridge: Cambridge University Press.

Tomlinson, B. Materials development. (2012) In J. Richards \& Burns, A. (Eds) The Cambridge Guide to Pedagogy and Practice in Second Language Teaching. Cambridge: Cambridge University Press. 